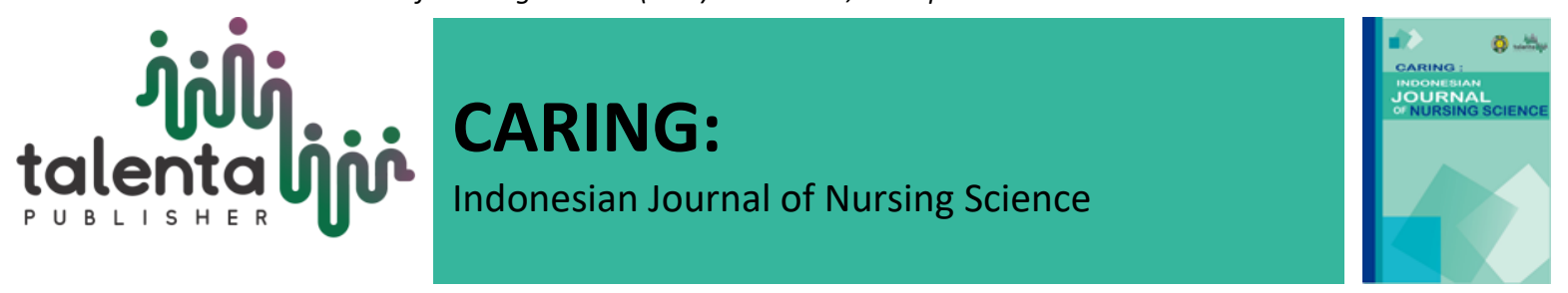

\title{
Mother's Knowledge on Diarrhea in Toddlers at Sangkunur Community Health Center
}

\section{Connie Melva Sianipar}

\author{
STIKes Santa Elisabeth, Medan, Indonesia
}

\begin{abstract}
Diarrhea is the second leading death cause in toddlers after pneumonia. It is a disease that often occurs in seemingly healthy toddlers. In Indonesia, every child has 1.6-2 times diarrhea episodes per year. This study aims to find out how thoroughly the mother's knowledge of diarrhea in toddlers at Sangkunur Community Health Center in 2019. This research was conducted by collecting data through a research questionnaire. The sample is 33 mothers who brought their toddlers to the community health centre. The result is most mothers have poor knowledge of diarrhea in their toddlers. Twenty-two respondents $(66.67 \%)$ had a good understanding of the diarrhea definition. Twenty-three respondents $(67.70 \%)$ had a poor understanding of diarrhea causes. Twenty-five respondents $(75.76 \%)$ had a poor understanding of diarrhea signs and symptoms. Twenty-two respondents $(66.67 \%)$ had a poor understanding of diarrhea prevention, and 29 respondents $(87.88 \%)$ had a poor understanding of diarrhea management. The conclusion is community health centres should be more active in providing counselling about diarrhea and visit people's houses to give further information regarding diarrhea.
\end{abstract}

Keyword: age; education; knowledge; sign; symptoms

Received $14^{\text {th }}$ April 2021| Revised $10^{\text {th }}$ June $2021 \mid$ Accepted $9^{\text {th }}$ July 2021

*Corresponding author at: Jl. Bunga Terompet No. 118, Sempakata, Kec. Medan Selayang, Medan, Indonesia

E-mail address: conniemelva@gmail.com 


\section{Introduction}

Diarrhea is an excessive loss of fluid and electrolytes occurring due to watery bowel movement, resulting in watery stools ${ }^{(15)}$. It is watery defecation happening to a person more than three times without any blood or mucus in the stool ${ }^{(14)}$. It happens commonly to seemingly healthylooking toddlers. Due to this, diarrhea has caused deaths in infants $(31.4 \%)$ and toddlers (25.2\%). Every year, 162,000 toddlers died from diarrhea, or 460 toddlers died per day. According to a household health survey (Survei Kesehatan Rumah Tangga - SKRT) conducted by the Indonesia Ministry of Health, Diarrhea is the second leading death cause in toddlers after pneumonia. They have 1.6-2 times diarrhea episode per year, and each of Indonesia's toddlers ever has it once (Indonesia Ministry of Health, 2011).

UNICEF reported that many children died from diarrhea every second - making it the number one cause of toddler's death. WHO estimated that there were four billion cases of diarrhea in the world during 2009, and 2.2 million people died - mostly are toddlers. In Indonesia, children's deaths from diarrhea have decreased from 385,000 in 1990 to 152,000 in 2012 . However, there are still more than 400 children who died of diarrhea every day in Indonesia. It commonly happens to the poorest and most marginalized families making them the victims of diseases (diarrhea and pneumonia) that should be easily preventable and treatable. Thus, we need to ensure that prevention and treatment services are available to every child in Indonesia (Maternal \& Child Health, 2012).

Another data from the morbidity survey conducted by the Sub-Directorate of Diarrhea, Indonesia Ministry of Health, from 2012-2015 showed an increasing incidence trend. In 2012, the diarrhea morbidity rate was 900 cases per 1,000 toddlers. There were $6.7 \%$ (provincial rate was $3.3 \%-10.2 \%$ ) of diarrhea incidence in 2013, and there were 18 diarrhea outbreaks with 1,213 patients and 30 deaths in 2015. The Case Fatality Rate was 2.47\% (Indonesia Ministry of Health, 2011).

Based on the data obtained from the Health Department of North Sumatra Province, there were 29,375 diarrhea cases in 2011 and 29,769 cases in 2012 in Medan city. Overall, the diarrhea cases in North Sumatra tended to increase. There were 215,651 diarrhea cases in North Sumatra throughout 2011, with 212,729 cases were treated at health facilities.

Apart from Medan, several regencies had the most diarrhea cases in 2011. Deli Serdang had 17,529 cases, Langkat had 14,175 cases, Serdang Bedagai had 11,962 cases (three deaths), and Simalungun had 32,428 cases. In 2012, Medan still placed first with 29,769 cases of diarrhea, followed by Deli Serdang (20,535 cases), Langkat (15,477 cases), Simalungun (27,943 cases, one death), and North Labuhan Batu (12,253 cases). 
Toddlers often had diarrhea due to their weak immune system, making them vulnerable to the virus causing diarrhea. When a toddler has diarrhea, the symptoms include watery stool, blood or mucus in the stool, high fever, abdominal bloating, abdominal pain, and vomiting. If the toddler looks flimsy due to repeating bowel movements along with abdominal pain or heartburn, the mother must be aware of it. She should perform a treatment on the toddler immediately. Mothers with limited knowledge and guidance regarding handling diarrhea symptoms on toddlers should be looked after more because sufficient knowledge is a significant domain in the stimuli process to shape behavior.

Therefore, properly handling diarrhea will reduce the disease severity. One should maintain cleanliness and process clean and healthy food. Also, the mother should be given sufficient knowledge regarding how to avoid and treat diarrhea fast and precisely. Thus, decreasing diarrhea morbidity and mortality numbers (Subagyo \& Santoso, 2010). In addition, a mother's sufficient knowledge regarding diarrhea is one of the predisposition factors shaping her treatment of toddlers who have diarrhea (Notoatmodjo, 2012).

Since the mother is the closest person a toddler has, she has a vital role in maintaining her toddler's health. She can determine toddlers' safety who have diarrhea. It starts with knowing what diarrhea is, its symptoms, causes, effects, and complications caused by diarrhea until providing first aid to prevent dehydration and treatment before the toddlers receive further treatment by health workers. Hence, a mother's ability is assessed by the mother's knowledge and treatment in handling diarrhea.

According to Kosasih et al. (2015), a mother's knowledge regarding diarrhea in toddlers can be seen in this overview as follows. In Suka village, $60 \%$ of respondents have good knowledge regarding diarrhea, 38\% have sufficient knowledge, and 2\% have poor knowledge. Another research results stated that the statistics of the mother with good knowledge regarding diarrhea are as follows 58 mothers (54.2\%), 33 women aged 20-35 years old (55.9\%), 31 high schooleducated mothers (55.4\%), and 49 housewives (80.3\%).

Mariastuti's research (2016) on mother's knowledge regarding diarrhea in toddlers at North Ponorogo Community Health Centre found that 50 respondents had good knowledge of diarrhea (66.66\%), 25 respondents had sufficient knowledge of diarrhea (33.34\%), and no respondents have poor knowledge of diarrhea. Research by Sitorus et al. (2015) conducted at Pegangsaan Dua Sub-District, North Jakarta, stated that 78\% answer correctly in diarrhea "definition", 62\% answers correctly in "causes" of diarrhea, $72 \%$ answers correctly in "signs and symptoms" of diarrhea, 72\% answers correctly in "handling" diarrhea properly, and 78\% answers correctly in "prevention" of diarrhea. The mean rate of respondents' correct answers regarding diarrhea's 
definition, causes, signs and symptoms, proper handling, and prevention was $72 \%$. This data showed that 50 respondents have moderate knowledge of diarrhea in toddlers.

Suma's research (2013) found that among 104 samples, 29 respondents have poor knowledge of diarrhea resulting in severe dehydration (28 respondents, 96.5\%) and mild dehydration (1 respondent, 3.44\%). On the other hand, 75 respondents have good knowledge of diarrhea.

Based on the identified research above regarding the overview of mother's knowledge on diarrhea in toddlers, it can be concluded that the issue persists on the lack of information or not conducting healthy lifestyle causing unwillingness to learn handling and prevention of diarrhea (Alimul, 2011). Fitri's (2016) research also stated that, statistically, mothers with poor knowledge of diarrhea would have their toddlers have diarrhea 7.1 times riskier. This supports the idea that a mother's knowledge of diarrhea could be a potential risk factor for the incidences of diarrhea in toddlers.

In terms of this research, the researcher had conducted a preliminary study by interviewing the health workers of Sangkunur Public Health Centre. It was found that 952 mothers who had toddlers were recorded in the Community Health Centre database in 2018. In January-February 2019, 33 toddlers had diarrhea visiting Sangkunur Community Health Centre for treatment. Based on this information and other variables such as the high incidence number of toddlers with diarrhea, the importance of diarrhea treatment, and the mother's diarrhea knowledge in Sangkunur Community Health Centre intrigue the author's interest in exploring more. Thus, conducting research titled "Mother's Knowledge on Diarrhea in Toddlers at Sangkunur Community Health Center in 2019."

\section{Research Method}

This research is a quantitative study using descriptive research. The descriptive method is a research method to picture a situation objective (Setiadi, 2013). This study aims to describe mothers' knowledge about diarrhea in toddlers at Sangkunur Community Health Center. This research was conducted by collecting data through structured questions or research questionnaires. The population in this study was 33 mothers who brought toddlers with diarrhea to Sangkunur Community Health Center. The questionnaire used was standardized from Fitri's research (2017), consisting of 19 statements. Data collection was carried out at the Sangkunur Community Health Center, South Tapanuli Regency. After obtaining a research approval letter from the community health center, the researcher visited prospective respondents using the Accidental Sampling technique. Researchers identified respondents who met the inclusion criteria, namely mothers who had toddlers and read and write. The researcher conducted an 
approach and explained the research and questionnaire. Then, asked the respondents to sign the informed consent. After the data was collected, the researcher conducted a univariate analysis, namely data processing and data analysis, using a computer (Software Analysis).

\section{Research Results}

Below are the research results of Mother's Knowledge on Diarrhea in Toddlers at Community Health Center 2019.

Table 1. Respondents' Frequency Distribution Based on Age

\begin{tabular}{lcc}
\hline Characteristics & $\mathbf{f}$ & $\%$ \\
\hline$<20$ years old & 9 & 27.27 \\
21- 35 years old & 10 & 30.30 \\
$36-45$ years old & 14 & 42.42 \\
\hline Total & $\mathbf{3 3}$ & $\mathbf{1 0 0}$ \\
\hline
\end{tabular}

The research result above showed that there are 14 respondents aged 36-45 years old included in the highest percentage of age $(42.42 \%)$, nine respondents aged $<20$ years old included in the lowest percentage (27.27\%), and ten respondents aged 21-35 years old (30.30\%).

Table 2. Respondents' Frequency Distribution Based on Education

\begin{tabular}{lcc}
\hline Education & f & \% \\
\hline Not completing elementary school & 2 & 6.06 \\
Elementary School & 14 & 42.42 \\
Junior High School & 4 & 12.12 \\
High school & 8 & 24.24 \\
& 5 & 15.15 \\
\hline Total & $\mathbf{3 3}$ & $\mathbf{1 0 0}$
\end{tabular}

The research result above showed 14 respondents with the highest percentage in terms of education $(42.42 \%)$. They are elementary school graduated. Also, only two respondents did not finish elementary school - taking the small portion percentage $(6.06 \%)$ in the total.

Table 3. Respondent's Frequency Distribution Based on Diarrhea's Definition

\begin{tabular}{lcc}
\hline Definition & Frequency & Percentage \\
\hline Correct & 22 & 66.67 \\
Wrong & 11 & 33.33 \\
\hline Total & $\mathbf{3 3}$ & $\mathbf{1 0 0}$
\end{tabular}


The research result above showed that most respondents (22 respondents) have good knowledge of diarrhea, taking the highest percentage, $66.67 \%$. 11 respondents have poor knowledge of diarrhea with $33.33 \%$.

Table 4. Respondents' Frequency Distribution Based on Diarrhea's Causes

\begin{tabular}{lcc}
\hline Cause & Frequency & Percentage \\
\hline Correct & 10 & 30.30 \\
Wrong & 23 & 67.70 \\
\hline Total & & $\mathbf{1 0 0}$ \\
\hline
\end{tabular}

The research results above showed that most respondents (23 respondents) have poor knowledge regarding diarrhea's causes, taking the highest percentage, $67.70 \%$. Ten respondents have good knowledge regarding diarrhea's causes with $30.30 \%$.

Table 5. Respondents' Frequency Distribution Based on Diarrhea's Signs and Symptoms

\begin{tabular}{lcc}
\hline Signs and Symptoms & Frequency & Percentage \\
\hline Correct & 8 & 24.24 \\
Wrong & 25 & 75.76 \\
\hline Total & $\mathbf{3 3}$ & $\mathbf{1 0 0}$ \\
\hline
\end{tabular}

The research result above showed that most respondents ( 25 respondents) have good knowledge of diarrhea's signs and symptoms, taking the highest percentage, 75.76\%. Eight respondents have poor knowledge of diarrhea's signs and symptoms, with $24.24 \%$.

Table 6. Respondents' Frequency Distribution Based on Diarrhea's Prevention

\begin{tabular}{lcc}
\hline Prevention & Frequency & Percentage \\
\hline Correct & 11 & 33.33 \\
Wrong & 22 & 66.67 \\
\hline Total & $\mathbf{3 3}$ & $\mathbf{1 0 0}$ \\
\hline
\end{tabular}

The research result above showed that most respondents (22 respondents) have poor knowledge to prevent diarrhea, taking the highest percentage, 66.67\%. 11 respondents have good knowledge to prevent diarrhea, with $33.33 \%$.

Table 7. Respondents' Frequency Distribution Based on Diarrhea Management

\begin{tabular}{lcc}
\hline Management & Frequency & Percentage \\
\hline Correct & 4 & 12.12 \\
Wrong & 29 & 87.88 \\
\hline Total & $\mathbf{3 3}$ & $\mathbf{1 0 0}$ \\
\hline
\end{tabular}


The research result above showed that most respondents (29 respondents) have poor knowledge about diarrhea management, taking the highest percentage, $87.88 \%$. Four respondents have good knowledge regarding diarrhea management, taking the small percentage, with $12.12 \%$.

\section{Research Discussion}

\section{a. Age}

Based on the research result above, the highest percentage in terms of age is $42.42 \%$, comprising 14 respondents aged $36-45$. The smallest percentage is $27.27 \%$, comprising of respondents aged $<20$ years old. This difference in age range depicts the maturity of a mother to have a child. Meanwhile, the productive age of a woman to get pregnant is 22-35-years old, so women aged 36-45 years old certainly have had children. The statement aligns with Asnidar's (2016) research, stating that too young women have not prepared themselves properly to have a child. Thus, making them reluctance to find more information regarding their babies. It is also aligned with Natoatmodjo's (2012) research stating that age affects one's understanding and mindset. As one gets older, her understanding and mindset develop better and better. Thus, acquiring better knowledge. If one becomes old and has many children, some will say that it is no longer the time for them to study. It is time for focusing their attention on taking care of their family.

\section{b. Based on education}

Based on the research result above, the highest percentage in education is $42.42 \%$, comprising 14 elementary school graduates' mothers and 6.06\% ( 2 respondents) mothers not completing elementary school. Aligning with Budiman and Riyanto's (2013) research, education is essential, and all people should receive a proper education. This is because the higher one's education, she will have a broader mind and knowledge. If one has broader knowledge, she will be better at living a healthy life, specifically for mothers looking after their family's needs.

\section{c. Definition}

Based on the research result above, the highest percentage in mothers' knowledge regarding diarrhea's definition is $66.67 \%$, comprising 22 respondents with good knowledge and 11 respondents with poor knowledge with 33.33\%. Most respondents know about diarrhea since diarrhea is the most often heard disease to the public. This disease is susceptible to happen to a child. The statement also aligns with Muhammad's (2014) research stating that $78 \%$ of respondents answer diarrhea's definition correctly. 


\section{d. Causes of diarrhea}

Based on the research result above, the highest percentage in diarrhea's causes is $67.70 \%$, comprising 23 respondents having poor knowledge and ten respondents with good knowledge, taking a small percentage with $30.30 \%$. This is because the information on diarrhea causes and its chain transmission lacks the public, resulting in the mother's poor knowledge of the disease. This aligns with Muhammad's (2014) research stating that $62 \%$ of respondents did not know diarrhea's causes in their children.

\section{e. Signs and symptoms}

Based on the research result above, the highest percentage of diarrhea's signs and symptoms is $75.76 \%$, comprising 25 respondents having poor knowledge and eight respondents with good knowledge, taking a small percentage with $24.24 \%$. Most respondents only complete elementary school, affecting their mindset to understand what diarrhea's signs and symptoms are. This result aligns with Muhammad's (2014) research, stating that $72 \%$ of mothers answered questions about diarrhea's signs and symptoms in children incorrectly.

\section{f. Prevention of diarrhea}

Based on the research result above, the highest percentage in diarrhea prevention is $66.67 \%$, comprising 22 respondents with poor knowledge and 11 respondents with good knowledge, taking a small percentage with $33.33 \%$. The reason was that most respondents had sufficient knowledge of diarrhea. Thus, they did not know how to prevent it in their children. This result aligns with Muhammad's (2014) research, stating that $78 \%$ of mothers did not know how to prevent diarrhea.

\section{g. Management}

Based on the research result above, the highest percentage in diarrhea management is $87.88 \%$, comprising 29 respondents with poor knowledge and four respondents with good knowledge, taking a small percentage with $12.12 \%$. Most respondents had sufficient knowledge of diarrhea. They did not have proper education, and as they are getting older, they start to ignore health information provided by health workers. Thus, they did not know proper diarrhea management. This result aligns with Muhammad's (2014) research, stating that $72 \%$ of respondents did not know proper diarrhea management.

\section{Conclusion}

By utilizing the research result, it is expected that community health centers will be more proactive in conducting diarrhea counseling to the public and health workers to reduce diarrhea's incidence number. 


\section{REFERENCES}

[1] Ministry of Health of the Republic of Indonesia. (2011). Series of Clean and Healthy Living Behavior in Household, Jakarta.

[2] Ministry of Health of the Republic of Indonesia. (2011). Health Worker Pocketbook: Cross Diarrhea. Directorate General Of Disease Control and Environmental Health, Ministry of Health, Republic of Indonesia, Jakarta.

[3] UNICEF. (2012). Maternal \& Child Health, UNICEF Indonesia, Indonesia.

[4] Fitri, S.M. (2016). Description of Mother's Knowledge Level About Diarrhea in Children Under Five in The Working Area of Puskesmas Pamulang, South Tangerang. Available:http://repository.uinjkt.ac.id/dspace/handle/123456789/36639, retrieved, Jan, 2020.

[5] Kosasih. et al. (2015). A Description of Mother's Knowledge of Diarrhea in Toddler Children in The Village at Suka. Indonesian Nursing Education Journal Vol. 1, No. 2.

[6] Sitorus, et al. (2015). Description Of Mother's Knowledge Level About Diarrhea In Toddlers in RT 01 And 02 RW 004 Pegangsaan Dua Urban Village, North Jakarta 2014. Jurnal. Husada Karya Jaya, Vol. 1, No.1.

[7] D. Mariastuti. (2016). Mother's Knowledge Level About Diarrhea in Toddlers Aged 1-5 Years in The Work Area of North Ponorogo Community Health Center. Muhammadiyah University of Ponogoro.

[8] S. Notoatmodjo S. (2012). Health Promotion and Health Behavior, PT. Rineka Cipta. Jakarta.

[9] Suparno \& M. Estiani, (2015). Factors Related to The Incidence of Diarrhea in Children Under Five in Saung Naga Village, West Baturaja District. Ministry of Health Poltekes RI.

[10] A. Suma. Sarlin. (2013). Factors Associated with the Incidence of Acute Diarrhea in Toddlers in the Work Area of Bulango Utara Health Center, Bone Bolango Regency, Gorontalo: FIIKK, State University of Gorontalo.

[11] B. \& A. Riyanto. (2013). Capita Selekta Questionnaire Knowledge and Attitudes in Health Research, Salemba Medika, Jakarta.

[12] A. Hidayat. Alimul, (2011). Midwifery Research Methods and Data Analysis Techniques, Salemba Medika, Jakarta.

[13] A. Mansjoer. (2014). Capita Selecta of Medicine, Media Aesculapius, Jakarta.

[14] Suriadi \& Yuliani. (2010). Nursing Advice in Children, Sagung Seto, Jakarta.

[15] B. Subagyo \& N. B.Santoso, (2010). Acute Diarrhea. Textbook of Hepatology Gastroenterology, IDAI Publishing Agency, Jakarta.

[16] Setiadi. (2013). Concept and practice of nursing research writing (Ed.2), Graha Ilmu. Yogyakarta.

[17] Asnidar. (2015). Description of mothers knowledge and attitudes about the incidence of diarrhea in children at the Bontonompo II Public Health Center, Gowa Regency, Alauddin State Islamic University Makassar. Scientific papers.

[18] Saleh, Muhammad, H. (2014). Relationship Environmental Sanitation Conditions with The incidence of diarrhea in children under five at Baranti Health Center Work Area Sindrap Regency 2013. 